\title{
Rural Youth Participation in Agriculture in Zambia
}

https://dx.doi.org/10.4314/jae.v22i2.5

\section{Sichone Trevor}

Tobacco Board of Zambia

Email: trevorsichone@gmail.com

Phone: +260967414204

\section{Kwenye, Jane Musole}

Department of Plant and Environmental Sciences

School of Natural Resources

Copperbelt University, Kitwe, Zambia

Emails: Jane.kwenye@yahoo.com ; jane.kwenye@cbu.aczm

Phone: +260971634617

\section{Abstract}

This study assessed rural youth participation in agriculture and the constraints they face in view of identifying ways of enhancing rural youth involvement in agriculture. Data for the study were collected from eighty rural youths in Kafue, Itimpi and Luangwa agriculture blocks of Kitwe district using a self-administered questionnaire. Results showed that rural youth involvement in agriculture serves as a source of income generation and provides the much needed labor force in critical farming activities among others. The results also revealed that rural youth involvement in agriculture is characterized with constraints that include lack of access to capital, poor storage facilities, poor road networks, poor access to agriculture insurance for farm produce, and lack of technical assistance. To increase rural youth participation in agriculture, the study recommends the need to address the challenges rural youths face whilst promoting interventions that reinforce the benefits the youths derive from participating in agriculture.

Keywords: Agriculture, rural youth participation, challenges

\section{Introduction}

Agriculture remains an important source of national income for most developing countries (Mashindano, Kayunze, Corta, and Maro, 2011). For instance, the agricultural system in Iraq is the third contributor to the country's gross domestic product (Administration for Children and Families and Food and Agriculture Organization, 2014). Furthermore, for many countries, the production of agricultural commodities, both for domestic use and export is an important source of economic growth and livelihoods (United Nations Environment Programme, 2011). According to United Nations Environment Programme (2011) approximately 2.6 billion people depend on agriculture for livelihood, the majority of whom are small holder farmers in rural areas. Hence, agricultural growth can reduce poverty directly by raising farm incomes and indirectly, through labour markets and reduction of food prices (World Bank, 2008). 
In order to foster a country's economic development, the agriculture sector must be viable and youths should be encouraged to effectively participate. This is because they are fundamental assets that any country can have (Kimaro, 2015) and constitute an important resource for sustaining agricultural productivity which is fundamental for economic development (Afande, Maina, and Maina, 2015). They are also among the most productive individuals in any society given that they are resilient, persevering and resourceful stakeholders in developmental processes (Naamwintome and Bagson, 2013). Additionally, compared to the older population, youths are the ideal catalysts for agricultural developmental change given their greater ability and willingness to adopt new ideas, concepts and technology which are all critical to transforming the agriculture sector favorably (Afande et al., 2015).

Youth have qualities which when nurtured and utilized are invaluable assets to agricultural and rural development. These qualities include great physical strength, innovation proneness, minimal risk aversion and faster rate of learning among others (Jibowo and Sotomi, 1996). Moreover, with dynamism and flexibility, extraordinary resilience and ability to cope even in most adverse and risky situations, youths have the potential to foster enhanced agricultural productivity (Naamwintome and Bagson, 2013). Consequently, fostering youth involvement in agriculture is a worthwhile investment (Ahaibwe, Mbowa and Mayanja, 2013). However, while youth involvement in agriculture is fundamental for economic development and poverty reduction, the significance and constraints associated with rural youth involvement in agriculture remains poorly understood in most developing countries, especially Zambia.

\section{Purpose of the study}

The overall objective of the study was to gain an understanding of the significance and constraints associated with rural youths' involvement in agriculture in Zambia using a case study of Kitwe district. Specifically, the study sought to:

i. determine the significance of rural youth participation in agriculture; and

ii. investigate the constraints to rural youth participation in agriculture

\section{Methodology}

This study was conducted in Kitwe district of Zambia. Kitwe is located in the heart of the Copper belt province and lies on latitudes $12^{\circ} 49^{\prime}$ south and longitudes $28^{\circ} 12^{\prime}$ east (Figure 1). It covers a total surface area of $31,014 \mathrm{~km}^{2}$ and has a population of 504,000 people (Central Statistics Office, 2010). Kitwe is well known for industrial and commercial activities on which a number of its residents depend for their livelihood. Agricultural activities are also undertaken in some part of the district. Consequently, Kitwe has three farming blocks namely Kafue, Itimpi and Luangwa, which are further divided into farming camps and zones. 


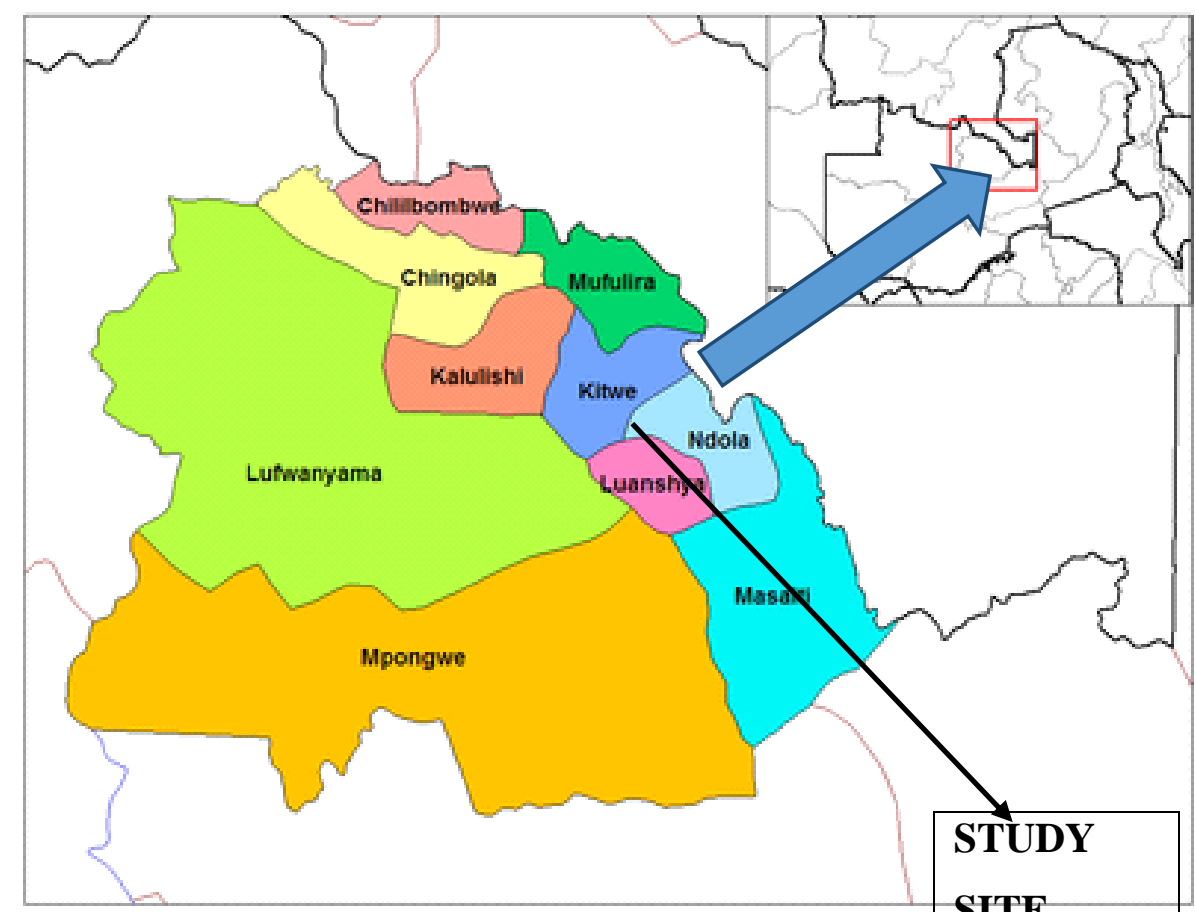

Figure 1: Map of Zambia and Copper belt Province showing the location of Kitwe.

(Source: Google maps)

Data were collected using both primary and secondary sources. Secondary data sources included peer-reviewed journals, text books, conference papers, and intergovernmental organization reports. Primary data was collected using a selfadministered questionnaire and analysed using the IBM SPSS Statistics Package (SPSS version 22) and Microsoft Excel. No complete sampling frame was available for the study population, as such, it was not possible to undertake a probability sampling method. Therefore, a convenient sampling method was used in this study. This approach is appropriate in instances where a sampling frame is unavailable (Lee, 2003). Due to similarities in physical and socio-economic characteristics in the communities, one agriculture block from each farming camp in the study area was selected for this study (Table 1). A total of eighty questionnaires were administered. Given that the questionnaires were administered on-site the response rate was 100 $\%$.

Table 1: Number of respondents in the agriculture camps and blocks

\begin{tabular}{llll}
\hline No. & Agriculture Camp & Agriculture Block & Number of Respondents \\
\hline 1 & Kakolo & Kafue & 25 \\
2 & Twatasha & Itimpi & 25 \\
3 & Chisokone & Luangwe & 30 \\
& Total & & 80 \\
\hline
\end{tabular}


A four weeks' period between $31^{\text {st }}$ December, 2015 and $27^{\text {th }}$ January, 2016 was used to collect data for this study. This data collection was chosen because it provided the opportunity to survey a representative sample of rural youths in the study area. On each day of the data collection period, the first respondent to participate in the survey was determined by selecting every fourth available respondent upon commencing the data collection. Thereafter, every available respondent was requested to participate in the survey.

\section{Results and Discussions}

\section{Demographic Characteristics of Respondents}

Table 2 presents the demographic profile of the respondents. The results showed that the majority of the respondents were female constituting 55 percent of the total sample. This finding provides support for past studies that noted that women are responsible for providing a larger proportion of agricultural labour on the African continent (Cheryl, 2011; FAO, 1984; United Nations Economic Commission for Africa, 1972). FAO (2011) note that females are more involved in agriculture because income realized from agricultural activities is considered to be critical for improving their financial status.

Results of the study also show that the most represented age group was 31-35 years old constituting 48 percent of the total sample followed by the age group 26-30 years old representing 28 percent of the total sample. The least represented age group was 15-20 years' old which constituted only 6 percent of the total sample. The finding showed that the majority of the respondents were already in the productive age group and corroborates with past studies that also showed that youths in this age group tends to dominate agricultural activities (Adeogun, 2015; Nkang, Ajah, Abang and Edet, 2009). 
Table 2: Respondents' demographic profile

\begin{tabular}{|c|c|}
\hline Variable & Percent \\
\hline \multicolumn{2}{|l|}{ Gender } \\
\hline Female & 55.0 \\
\hline \multicolumn{2}{|l|}{ Age } \\
\hline $15-20$ years & 6.3 \\
\hline $21-25$ years & 18.8 \\
\hline $26-30$ years & 27.5 \\
\hline $31-35$ years & 47.5 \\
\hline \multicolumn{2}{|l|}{ Marital status } \\
\hline Single & 40.0 \\
\hline Married & 50.0 \\
\hline Divorced & 6.3 \\
\hline Widow(er) & 3.8 \\
\hline \multicolumn{2}{|l|}{ Education } \\
\hline Less than primary & 8.8 \\
\hline Primary & 50.0 \\
\hline Secondary & 35.0 \\
\hline Tertiary & 6.3 \\
\hline
\end{tabular}

The result also show that half of the respondents were married (50\%) followed by the singles $(40 \%)$ divorced $(6 \%)$ and the widows/widowers (4\%). This finding highlighted the greater involvement of married people in agricultural activities. It is widely agreed that married people usually have household responsibilities (FAO, 2011), thus the need to take care of household needs could be a major driver of married people's involvement in agricultural activities. The results also showed that half of the total sample had only attained primary education $(50 \%)$. Those who had attained secondary education constituted 35 percent of the total sample while those with tertiary education were in the minority constituting 6 percent of the total sample. This finding suggests that respondents with lower education levels participated more in agricultural activities than those who had attained higher education levels.

\section{Rural Youth Involvement in Agricultural Activities and Associated Constraints}

Table 3 shows that respondents were involved in various types of pre-farming and post-farming activities. The respondents' involvement in the agricultural activities presented in Table 3 showed that rural youths are an important source of labour that is critical for various agricultural activities. 
Table 3: Types of respondents farming activities

\begin{tabular}{ll}
\hline Farming activities & Percent (\%) \\
\hline Bush clearing & 91.2 \\
Cultivation & 96.2 \\
Planting & 100 \\
Weeding & 100 \\
Fertilizer application & 100 \\
Harvesting & 93.8 \\
Processing & 17.5 \\
Feeding livestock & 61.3 \\
Breeding & 5.0 \\
Selling farm produce & 85.0 \\
\hline
\end{tabular}

\section{Annual Income Earned from Agriculture Activities}

The results showed that respondents derived income from their sale of agricultural produce. However, as shown in Figure 1, a majority of the respondents derived meagre revenue from agricultural activities. This finding is similar to past studies that agricultural activities provide meagre revenue for youths. For instance, in a study that focused on cocoa farms in Nigeria. Adeogun (2015) reported that youth who participated in growing cocoa generated meagre income from the sale of cocoa. Low income generation from agricultural activities by the youths has implications on their motivation to participate in agriculture activities. Moreover, it hampers the financial strength to reduce the effects of constraints associated with agricultural activities such as pest and diseases.

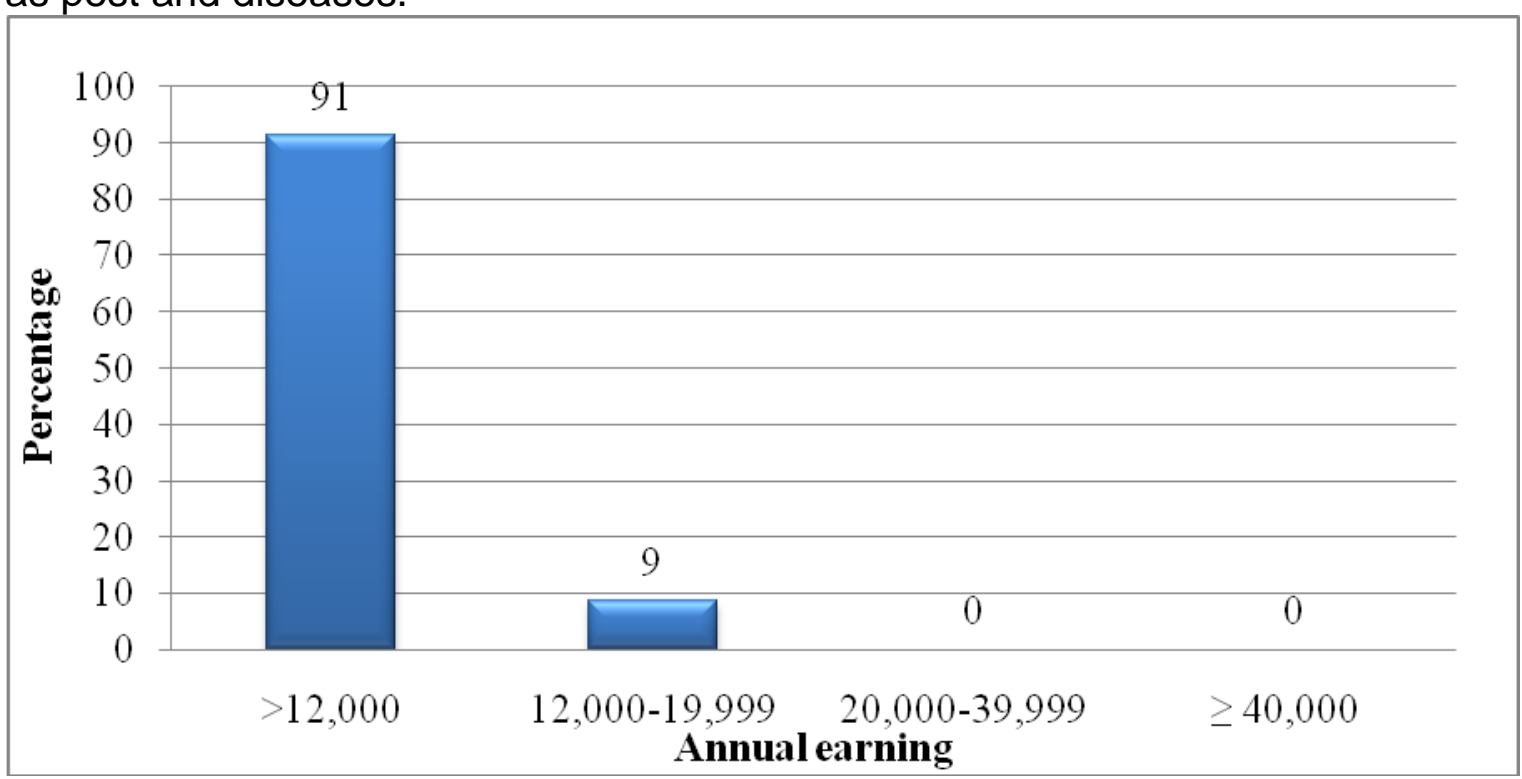

Figure 1: Annual income earned by the respondents from agriculture activities

\section{Major Assets Acquired Using Income Earned from Farming}

The result further show that respondents acquired various assets using income generated from the farming activities. Table 4 shows that the majority of the 
respondents acquired farming tools using income earned from farming activities $(98 \%)$. Those who purchased radios and bicycle constituted 92 percent and 56 percent of the total sample respectively. 14 percent and 13 percent of the total sample used earnings from farming activities to purchase furniture and land respectively. Only a small proportion of the total sample used income from farming activities to purchase a stove (1\%). Past studies have shown that agriculture is an important source of income (GRZ, 2011, World Bank, 2013). Thus, the findings of this study corroborate past studies by demonstrating that participation in agricultural activities facilitates generation of income that is useful for purchasing farming tools that are critical for sustaining agricultural activities.

Table 4: Major assets acquired using income earned from farming

\begin{tabular}{ll}
\hline $\begin{array}{l}\text { income from farming activities } \\
\text { Assets }\end{array}$ & Percent (\%) \\
\hline Farming tools & $98.7 \%$ \\
Bicycle & $55.7 \%$ \\
Television & $29.1 \%$ \\
Furniture & $13.9 \%$ \\
Radio & $92.4 \%$ \\
Land & $12.7 \%$ \\
Stove & $1.3 \%$ \\
\hline
\end{tabular}

\section{Factors Constraining Youth Involvement in Agriculture}

Entries in Table 5 present results of the factors constraining youth involvement in agriculture. The results showed that lack of access to capital (mean score 3.96) was the major factor constraining youth participation in agriculture. Afande et al., (2015) noted that access to finance provided by financial institutions is often difficult for most farmers because they do not possess collateral required by financial lending institutions. Lack of collateral may to a large extent explain the rural youth's inability to access capital. Lack of technical assistance with a mean score 3.90 was yet other challenge faced by the respondents. This finding suggests that agricultural extension services are not adequately provided for the rural youth. 
Table 5: Factors constraining youth involvement in agriculture

\begin{tabular}{lcc}
\hline Factors influencing youth participation & Mean & Std. Deviating \\
\hline Animal pests and diseases & 2.28 & 1.40 \\
Poor access to basic farming information & 2.48 & 0.98 \\
Poor road network & $2.79^{*}$ & 1.19 \\
Crop pests and diseases & $3.09^{*}$ & 1.40 \\
Labour intensive nature of agricultural & $3.39^{*}$ & 1.45 \\
activities & $3.40^{*}$ & 1.64 \\
Poor access to markets for farm produce & $3.46^{*}$ & 1.29 \\
Low prices of farm produce & $3.51^{*}$ & 1.26 \\
Poor access to land & $3.60^{*}$ & 1.37 \\
Poor storage facilities & $3.70^{*}$ & 1.10 \\
Poor access to agricultural insurance & $3.83^{*}$ & 1.13 \\
High cost of farming inputs & $3.90^{*}$ & 1.14 \\
Lack of technical assistance & $3.96^{*}$ & 1.29 \\
Lack of access to capital & &
\end{tabular}

\section{* Important}

Result of the study also show that the majority of the youth lacked access to capital. Lack of capital may explain why the majority of the rural youth were able to only cultivate less than a hectare of land for farming purposes. Afande et al., (2015) noted that access to finance provided by financial institutions is often difficult for most farmers because they do not possess collateral required by financial lending institutions. Lack of collateral may to a large extent explain the rural youth's inability to access capital. The findings also showed that lack of technical assistance was yet another challenge rural youth face in agriculture. This finding suggests that agricultural extension services are not adequately provided for the rural youth.

Table 5 further reveals that rural youths face constraints in purchasing agriculture inputs due to the high costs of farming inputs that could be associated with poor road networks in rural areas that tend to increase transportation costs. With increased transportation, the price of inputs in rural areas is likely to be high relative to urban areas that tend to have better road networks. Another constraint rural youths face is access to agricultural insurance for their farm produce. Past studies indicate that high cost of insuring farm products, lack of basic information on the importance of insuring agriculture products and failure to reach the insurance companies are some of the factors that hinder rural farmers from accessing farm insurance (Afande et al., 2015). Thus, an understanding of these factors is critical for determining factors that hinder access to agricultural insurance.

The findings also indicate that unavailability of appropriate storage facilities for stocking agriculture products was another constraint rural youth face in agriculture. This to a large extent results in great losses when perishable farm products such as vegetables and sweet potatoes are not sold on time. Results also showed that 
another constraint rural youth faced in the study area was ability to acquire land for farming activities. Ahaibwe et al. (2013) showed that large farm sizes make farming much more economically viable for the farmers by enabling them to reap economies of scale. Consequently, given that meaningful returns from agriculture can be fully realized when agriculture is undertaken on a large scale, difficulties in acquiring agricultural land hinders the youths' ability to expand their farming resource base.

\section{Conclusion and Recommendations}

Rural youth involvement in agriculture in Zambia serves as a source of income generation and provides the much needed labour force in critical pre-farming and post-farming activities. Their involvement in agriculture is characterized with constraints that include lack of access to capital, poor storage facilities, poor road networks, poor access to agriculture insurance for farm produce, and lack of technical assistance. To increase rural youth participation in agriculture, there is need to address these constraints. For instance, to enhance rural youth's access to capital, there is need to increase the pool of rural youth farmers that can benefit from accessing loans offered by government funded institutions such as the Citizens Economic and Empowerment Commission (CEEC). There is need to improve road networks so as to reduce inputs costs and increase the competitiveness of crops grown in rural areas relative to those grown in urban areas. Furthermore, improving market infrastructure such as storage facilities is fundamental in view of enhancing income generation from farming activities. Moreover, there is also need to encourage farm-output insurance by putting in place measures that can inform the rural youth on the importance of insuring their farm produce.

\section{References}

Adeogun, S.O. (2015). Participatory diagnostic survey of constraints to youth involvement in cocoa production in cross river state of Nigeria. Agricultural Sciences, 60 (2), 211-225.

Administration for Children and Families., and Food and Agriculture Organization (ACF., and FAO). (2014). Rapid Assessment of Agricultural Livelihoods. Tilkaif District, Ninewah Province.

Afande, F.O., Maina,W.N., and Maina, M.P. (2015). Youth engagement in agriculture in Kenya: Challenges and prospects. Culture, Society and Development, 7 , 2422-8400.

Ahaibwe, G., Mbowa, S., and Mayanja, M.L. (2013). Youth engagement in agriculture in

Uganda: Challenges and prospects. Unpublished Working Paper. Economic Policy Research Centre (EPRC).

Chreyl, D. (2011). The role of women. Agricultural Development Economics (ESA). The Food and Agriculture Organization. ESA working paper No. 11-02. 
Central Statistics Office. (2010). Census of population and housing. Lusaka, Zambia

Food and Agriculture Organization (FAO). (2011). The role of women in agriculture. Food and Agriculture Organization of the United Nations. ESA Working Paper No. 11-02.

Food and Agriculture Organization (FAO). (1984). Women in food production and food security in Africa. Food and Agriculture Organization of the United Nations, Rome, Italy.

Government of the Republic of Zambia (GRZ). (2011). Zambia's Report on the Various Thematic Cluster of Issues submitted to the United Nations Commission on Sustainable Development (UNCSD -16). United Nations Organisation, New York, U.S.A.

Jibowo, A.A., and Sotomi, A, O. (1996). The youth in sustainable rural development: $A$ study of programmes in Odeda Local Government Area of Ogun state. Nigeria Rural Sociology Association (NRSA) proceedings.

Kimaro, P.J., Towo, N.N., and Moshi, B.H. (2015). Determinants of Rural Youth's Participation in Agricultural Activities. Economics, Commerce and Management, 3 (2), 1-47.

Lee, J. (2003). Examining the antecedents of loyalty in a forest setting: Relationships among service quality, satisfaction, activity involvement, place attachment and destination loyalty. PhD dissertation. The Pennsylvanian State University.

Mashindano, O., Kayunze, K., Corta L.D., and Maro F. (2011). Agricultural growth and poverty reduction in Tanzania 2000-2010: where has agriculture worked for the poor

and what can we learn from this? Working paper No. 208 Chronic Poverty Research

Centre ISBN: 978-1-908536-05-1.

Naamwintome, B. A., and Bragson, E. (2013). Youth in agriculture: Prospects and challenges in the Sissala area of Ghana. Agricultural Science, 1(2), 60-68.

Nkang, N.M., Ajah, E.A., Abang, S.O., and Edet, E.O. (2009). Investment in cocoa production in Nigeria: A cost and return analysis of three cocoa production management systems in the Cross River State cocoa belt. African Journal of Food, Agriculture, Nutrition and Development, 9(2), 713-727.

United Nations Environment Commission for Africa (UNECA). (1972). Women: The neglected human resource for African development. Canadian Journal of African Studies, 6(2), 359-370. 
Creative commons User License: CC BY-NC-ND

Abstracted by: EBSCOhost, Electronic Journals Service (EJS),

Google Scholar, Journal Seek, Scientific Commons,

Food and Agricultural Organization (FAO), CABI and Scopus
Journal of Agricultural Extension

Vol. 22 (2) June, 2018

ISSN(e): 24086851; ISSN(Print); 1119944X

http://journal.aesonnigeria.org

http://www.ajol.info/index.php/jae

Email: editorinchief@aesonnigeria.org

United Nations Environment Programme. (2011). Towards a green economy. Pathways to sustainable development and poverty eradication- $A$ synthesis for policy makers.

World Bank. (2008). World development report. Agriculture for development. Washington, DC. World Bank.

World Bank. (2013). Zambia's job challenges: Realities on the ground. Zambia Economic Brief. Lusaka, Zambia. 